\title{
RECONSTRUCTING HUMAN SUBSISTENCE STRATEGIES DURING THE KOREAN NEOLITHIC: CONTRIBUTIONS FROM ZOOARCHAEOLOGY, GEOSCIENCES, AND RADIOCARBON DATING
}

\author{
Kidong Bae ${ }^{1}$ Christopher $\mathrm{J} \mathrm{Bae}^{2} \cdot$ Jong Chan $\mathrm{Kim}^{3}$ \\ ABSTRACT. The Neolithic in Korea began around 10,000 BP and is the period when many substantial changes appear in \\ the archaeological record. In particular, one of the important changes is from a subsistence strategy that relied primarily on \\ hunted, fished, and collected food packages to a diet that by the beginning of the Bronze Age ( $\sim 3500 \mathrm{BP})$ saw intensive agri- \\ culture as the primary form of sustenance. This paper discusses current research on this topic, in addition to presenting a com- \\ prehensive list of raw accelerator mass spectrometry (AMS) data from Korean Neolithic sites, particularly data that only \\ became available over the past several years.
}

\section{INTRODUCTION}

Almost immediately following the end of the Pleistocene and the beginning of the Holocene, a number of major cultural changes appear in Korea (Choe 1982; Kim 1986; Nelson 1993; Lee 2001; Choe and Bale 2002; Kim 2002; Norton 2007). The primary change is the transition from the Late Paleolithic $^{4}$ to the Neolithic, which occurs sometime around 10,000 BP (Choe and Bale 2002; Norton 2007; Norton et al. 2007). Although few studies appear to focus on this important transition in Korea (e.g. Norton et al. 2007; Seong 2007), a number of major behavioral changes appear to be present. In particular, pottery, ground stone tools, and fishing equipment appear for the first time during the latter period, eventually phasing out artifact industries like microliths that appear during the Late Paleolithic (Norton 2000a; Choe and Bale 2002; Norton et al. 2007; Bae and Bae 2012). In Korea, the Neolithic is defined by the introduction of pottery, with the most common type a comb-incised style, conical base shaped pot. However, it should be noted that regional variation in Korean Neolithic pottery styles exist. For instance, flat-bottom applique-style pottery appears in the southern part of the peninsula. The Neolithic pottery design is usually referred to as Chulmun or Bissalmuneui and some researchers use these pottery terms to represent this cultural period (e.g. Choe and Bale 2002; Lee 2011). The advent of the Bronze Age in Korea is defined by the introduction of a new pottery style, Mumun or plainware design, and not by the actual introduction of bronze artifacts, which appears to lag behind the appearance of Mumun pottery by at least several centuries. As with the Neolithic, which is sometimes referred to as the Chulmun, the Korean Bronze Age is sometimes referred to as the Mumun period (e.g. Lee 2011). In order to remain consistent with previous studies (e.g. Norton 1996, 2000a, 2007; Norton et al. 1999; Kim 2002; Bae and Kim 2010; Kim and Bae 2010), we will continue to refer to these 2 cultural periods as the Neolithic and Bronze Age.

One of the most debated topics in Korean archaeology that focuses on this time period is the subsistence transition from one that relied heavily on hunted, fished, and gathered food during the Neolithic $(\sim 10,000-3500 \mathrm{BP})$ to one that came to rely more heavily on plant domesticates during the Bronze Age ( $3500-2300 \mathrm{BP})$. A variety of models have been proposed to explain this transition, from migrations from the north, to different adaptations due to food stresses possibly in the face of increasing population densities and/or environmental fluctuations, to rising social complexity (e.g.

\footnotetext{
${ }^{1}$ Department of Anthropology, Hanyang University, Ansan, Gyunggi Province, Republic of Korea.

${ }^{2}$ Department of Anthropology, University of Hawai'i at Manoa, 2424 Maile Way, 346 Saunders Hall, Honolulu, Hawaii 96822, USA. Corresponding author. Email: cjbae@hawaii.edu.

${ }^{3}$ Department of Physics, Seoul National University, Seoul, Republic of Korea.

${ }^{4}$ As defined by Gao and Norton (2002).
} 


\section{K Bae et al.}

Choe 1982; Kim 1986; Rhee and Choi 1992; Norton 1996; Lee 2001; Kim 2002, 2010; for recent reviews see Norton 2007; Lee 2011). In this paper, we present accelerator mass spectrometry (AMS) data analyzed in the Seoul National University AMS Laboratory and data culled from recent published sources (Appendix, see Supplemental Data of the online version of this article; see also Bae and Kim 2010; Kim and Bae 2010). The AMS dates were calibrated using CALIB 6.1 (Stuiver and Reimer 1993) and IntCal09 (Reimer et al. 2009). We then integrate these new data into the debate about the nature of subsistence transitions during the Early and Middle Holocene in Korea. In particular, we review recent explanations for the subsistence transition and evaluate the argument that increasing population pressure through migrations and/or long-term sedentism was not a factor in the transition from fishing-hunting-gathering to full-scale agriculture during the Middle to Late Holocene. However, it is beyond the scope of the present paper to evaluate the different models proposed to explain this major food transition.

\section{HUMAN SUBSISTENCE STRATEGIES IN NEOLITHIC KOREA}

"Despite some degree of plant cultivation, the central-western Korean LC [Late Chulmun, 3500-1300 BC] subsistence economy is thought to have depended predominantly on hunting and gathering. Cultivation, if present at all, likely played a very limited role" (Kim 2010:85).

Although Kim (2010) was writing about a specific spatial-temporal point within the Republic of Korea (i.e. South Korea), there is strong and growing evidence from zooarchaeology and isotope research (e.g. Sample 1974; An 1991, 1994; Norton 1996, 2000a, 2007; Norton et al. 1999; Lee 2001; Choy and Richards 2009, 2010; Choy et al. 2012) that this pattern is likely applicable for much of the southern half of the Korean Peninsula and possibly most of the peninsula. Given the generally accepted fact that agriculture appears much earlier in China, and because of the close geographical connections between the northern part of the Korean Peninsula and the Chinese mainland, it would not be very surprising to see evidence of early agriculture in that region of the peninsula as well, particularly because it is generally accepted that plant domestication diffused from China to Korea. Nevertheless, most of our discussion focuses on the archaeologically better-known southern half of the Korean Peninsula.

The application of zooarchaeological methods to addressing questions of human subsistence strategies during the Neolithic and Bronze Age in Korea has traditionally been relatively rare (e.g. Sample 1974). Fortunately, over the past 2 decades a growing number of zooarchaeological studies have been done that analyze various aspects of human subsistence in Holocene Korea (e.g. An 1991, 1994; Norton 2000a, 2007; Norton et al. 1999; Lee 2001). These faunal studies showed fairly consistently that Korean Neolithic peoples regularly hunted, fished, and gathered for a living and that coastal peoples consumed a proportionately larger amount of proteins and nutrients from the sea. At least some of these studies have shown that even in the face of environmental fluctuations (e.g. paleobathymetric variation) and territorial circumscription that may have contributed to seasonal periods of dietary stress, that Holocene peoples were able to adapt to survive. For instance, An (1991) showed through seasonality studies that the central-west coast Konam-ri peoples would have been able to survive comfortably in the region through a combination of seasonal hunting, fishing, and collecting activities. By the advent of the Bronze Age, people replaced much of the hunted and fished food with nutrients tilled from the land (i.e. full-scale rice agriculture; Norton 2000a, 2007). It should be noted that many studies (e.g. Rhee and Choi 1992; Choe and Bale 2002; Norton 2007) have indicated that small-scale cultivation of millet was probably present in Korea by the Middle Neolithic $(\sim 5500-4200$ BP). Thus, few would disagree that by at least the Middle Holocene, Korean foragers had added at least small-scale plant cultivation to their broad spectrum diet. 


\section{Human Subsistence Strategies During Korean Neolithic}

The results of recent isotope studies provide further support for 2 conclusions drawn from faunal analyses: 1) Despite a broad spectrum diet during the Neolithic, there appears to be a heavy emphasis on food procured from the sea; and 2) a marked difference is evident in the diets of Neolithic and Bronze Age Korean peoples (e.g. Choy and Richards 2009, 2010; Choy et al. 2012). For instance, Choy and Richards (2009:1312) concluded that "[h]uman bone collagen $\delta^{13} \mathrm{C}$ and $\delta^{15} \mathrm{~N}$ values indicate that there was some consumption of marine foods, although the main protein sources were from terrestrial foods" for the specimens analyzed from the Nukdo shell midden site, a locality with both Bronze Age and Iron Age deposits. Choy and Richards (2010:7) also found that their "isotopic data suggest that there is no isotopic indication of a significant contribution to dietary protein from $\mathrm{C}_{3}$ plants such as rice in the Tongsamdong site," which corroborates other studies that indicate little to no evidence of rice agriculture until after the advent of the Bronze Age (e.g. Kim 2002; Ahn 2010; Lee 2011). It should be noted that we are not arguing here that all Korean Neolithic people relied primarily on a diet of hunted fish and sea mammals and gathered shellfish. Indeed, there is fairly abundant evidence from even coastal shell midden sites that deer, pigs, and birds were processed and consumed on a fairly regular basis (e.g. Konam-ri, Sangnodaedo, Tongsamdong). This goes along with the generally accepted fact that all foragers collected and processed plants (with plant domesticates entering the diet during the latter half of the Neolithic as discussed above).

Nevertheless, a recent study has tried to downplay the importance of the analysis of vertebrate faunas (from either zooarchaeological or isotopic perspectives) in reconstructions of dietary changes. For instance, Lee (2011: S313) writes "on the basis of one human remain, Choy and Richards (2010) suggest that the Chulmun people at Tongsamdong were largely dependent on marine protein resources," in turn partially using this evidence to conclude "limited numbers of cases cannot represent the dietary pattern of the entire Chulmun population" (emphasis added). Although it is true that paleobotanical studies in Korea are relatively new (Ahn 2010), the introduction of this type of analysis should not be equated with the discounting of all zooarchaeological and isotopic studies, particularly when attempting to reconstruct overall human diet, of which plant domesticates did not dominate until late in the prehistoric record. Unless one is trying to make the argument that Neolithic Korean foragers were vegetarians, hunted, fished, and gathered food (e.g. deer, wild boar, fish, birds, shellfish, etc.) must be included in reconstructions of overall human diet. The abovedescribed zooarchaeology and isotope studies have made many important contributions to deepening our understanding of Holocene Korean people's subsistence strategies, and contrary to Lee's (2011) interpretation of these data, do appear to present a fairly consistent pattern regarding Korean Neolithic people's diet.

In our view, Lee (2011) misrepresents research currently being done on evaluating changes in human diet during the Korean Neolithic and Bronze Age. For instance, Lee (2011: S311), citing the studies by “B. Kim 2006; J. Kim 2008; Norton 2007," argues that these authors, in making comparative analyses between the Neolithic (Chulmun) and Bronze Age (Mumun) create a "simple dichotomy" that "has further limited our understanding of the factors involved in the transition from the Chulmun to the Mumun, often described as an abrupt shift from hunting and gathering to agricultural societies." Although we cannot speak for the B Kim (2006) and J Kim (2008) studies, we can speak with confidence about Norton's studies (Norton 2000a, 2007; Norton et al. 1999), which for the most part stem from his Master's thesis (Norton 1996). Norton (2007:165) wrote "as evidenced from the Korean archaeological record, there is an increased use of plant domesticates and a decrease in other food sources during the Holocene. These changes in overall human diet breadth culminate with the Late Neolithic-Bronze Age ( $\sim 3500 \mathrm{BP})$ transition where dependence on hunted and gathered food packages decreases during the former period and full-scale agriculture becomes the norm during the latter cultural stage" (emphasis added). Thus, it is interesting to see that 


\section{K Bae et al.}

Norton's work is treated as creating a "simple dichotomy" when it comes to reconstructing Korean Neolithic and Bronze Age people's subsistence strategies. Perhaps even more interesting is that Lee (2011: S326) admits that evidence for what may be considered "full-scale agriculture" does not appear in Korea until the Early Bronze Age, when she writes "the clearest archaeological evidence for intensive agriculture in Korea is found in the Early Mumun by 3400 cal BP." In rereading the Norton studies, we are not sure how their conclusions differ that much from Lee's.

Lee's (2011) apparent misinterpretations have been compounded by others. For instance, in reviewing Lee's work, Zeder (2012:248) writes:

"Lee's [2011] documentation of the existence of such a broad spectrum food producing economy directly contradicts two previous models that placed the transition to agriculture 2000 years later in time, and assigned a causal role in this transition to either demographically induced resource pressure (Norton, 2000 [a]), or to environmentally driven migration and territorial circumscription (Kim, 2003, 2006).”

First, if Lee's research directly contradicts Norton (2000a), then she is also contradicting her own earlier work. Indeed, Crawford and Lee (2003:94) wrote that "Middle and Late Chulmun [Neolithic] cultures exhibit little, if any, significant alterations suggesting crops helped maintain Chulmun [Neolithic] lifeways rather than alter them." Perhaps the most parsimonious way of interpreting this statement is that Crawford and Lee (2003) for the most apart agree with other researchers (e.g. Norton et al. 1999; Norton 2000a, 2007; Kim 2010) that cultivated plants, though appearing during the latter stages of the Korean Neolithic, did not cause significant changes to overall subsistence strategies of Middle Holocene peoples.

Second, broad comparisons between Neolithic and Bronze Age human subsistence patterns in Korea do indeed indicate fairly significant variation. However, nowhere can we find that Norton and colleagues (Norton 1996, 2000a, 2007; Norton et al. 1999) argue that there was no variation in Neolithic subsistence strategies and the only things Korean Neolithic people ate were resources that were hunted, fished, and/or gathered and never consumed small-scale domesticated plant materials, which is an interpretation that could be drawn from Lee's (2011) work, or at least Zeder's (2012) interpretation of the former person's research (see Zeder's quote above). For instance, Norton et al. (1999:152) originally stated "The subsistence patterns of Chulmun [Neolithic] peoples of the Korean Peninsula have been termed 'broad spectrum' in that they apparently relied on food resources obtained through hunting, fishing, and collecting activities. Millet agriculture appeared for the first time during the latter half of the Neolithic, but it has been argued that it only made up a small component of the overall diet." More recently, Norton (2007:138) wrote "the primary difference [between the Early Neolithic ( 8000-5500 BP) and the Middle Neolithic ( $\sim 5500-4200$ BP)] is that we begin to see clear evidence of the cultivation of wild cultigens (foxtail millet, barnyard millet) and stone tools normally associated with such activities (e.g. querns, digging sticks)." Furthermore, Norton (2007:138-9) specifically states "even though some of these transformations actually begin during the Middle-Late Neolithic, the changes become more pronounced once millet and rice agriculture became the subsistence base of Korean peoples during the Bronze Age" (emphasis added). Thus, we find it perplexing to see how Norton's research is being incorrectly presented by the recent studies by Lee (2011) and Zeder (2012).

Lee (2011) argues that increasing population pressure cannot be used to explain the subsistence transition. Indeed, citing Lim (2009) but providing no evidence, Lee (2011: S323) argues that "evidence of resource stress due to high population density in the Chulmun period is lacking." Here, we present the most comprehensive collection of Early and Middle Holocene AMS data from Korean archaeological sites (Figures 1a-b; raw data can be found in the Appendix (online Supplemental Data). Figure 1a presents the uncalibrated raw AMS dates, while Figure $1 \mathrm{~b}$ presents the calibrated 
Human Subsistence Strategies During Korean Neolithic

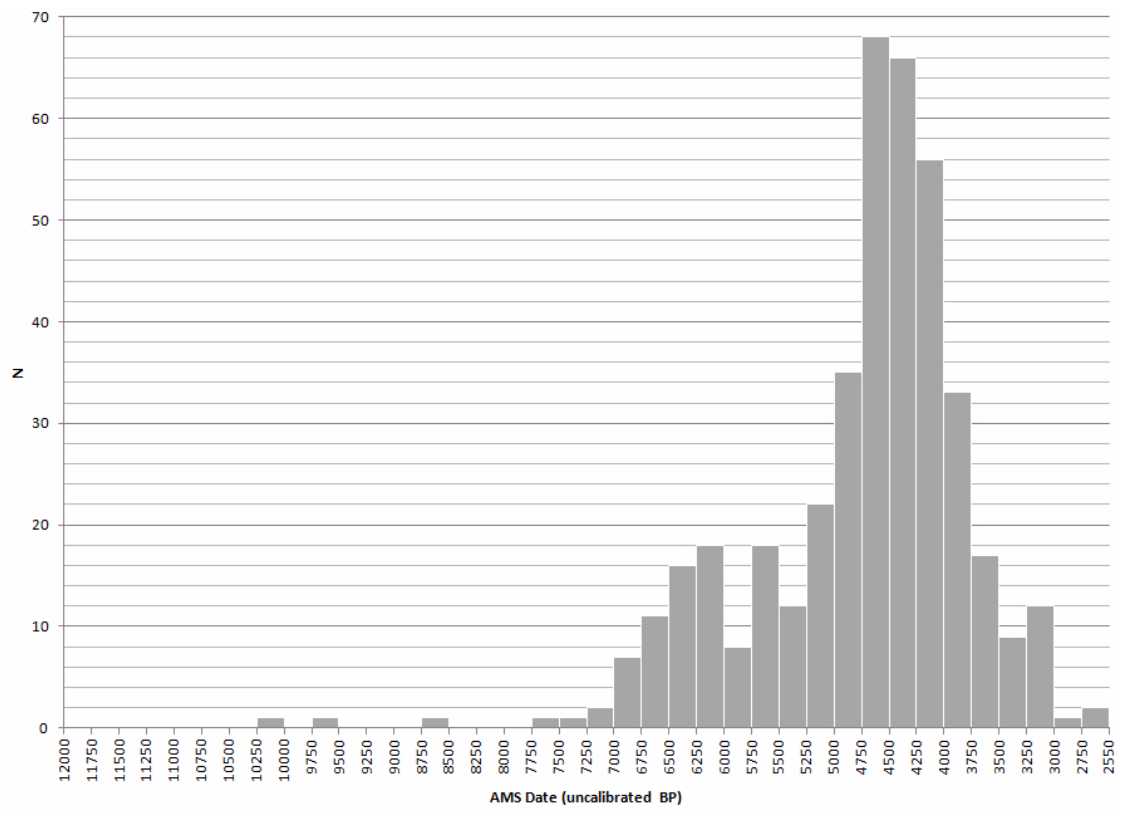

Figure 1A Uncalibrated AMS ${ }^{14} \mathrm{C}$ data (raw data presented in the Appendix, online Supplemental Data). Individual dates for individual sites were considered separate occupations except in cases where samples were collected from the same stratigraphic level. In the latter cases, the AMS dates were averaged and considered 1 occupation. The data were then assigned to 250 -yr arbitrary increments.

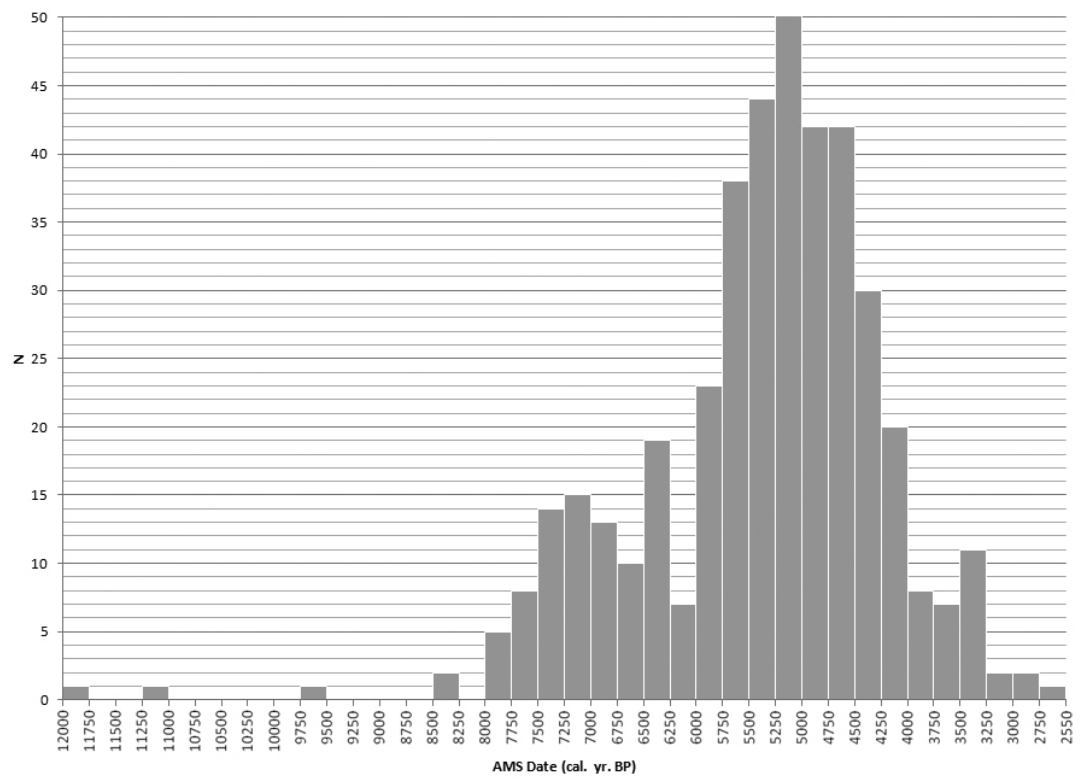

Figure 1B Calibrated AMS ${ }^{14} \mathrm{C}$ data at $1 \sigma(68.2 \%)$ (see Figure 1A caption for further information)

AMS dates. Not surprisingly, both charts present the same pattern in the data. Sometime around 7000 BP ( $\sim 8000$ cal BP), we begin to see a sharp increase in the number of occupations in Neolithic Korea. Interestingly, a sharper increase in occupation density appears right before the beginning of 


\section{K Bae et al.}

the Middle Neolithic ( $\sim 5500 \mathrm{BP})$, a time when millet appears in the archaeological record. Although it may be a pure coincidence that millet cultivation appears around the same time as we see this increase in occupation density, the data do seem to suggest increasing population density in the region may have played a role in the expansion of foraging diets to include plant domesticates. This is an argument others have made in the past (e.g. Norton 1996, 2000a, 2007), and the data appear to support this hypothesis. The question then becomes whether this increase in population density is primarily because of sedentary lifestyles over tens of generations, new migrations from other regions (e.g. northern China), or some combination of both factors. Although it is beyond the scope of the current study to address this latter question, comparative archaeological analyses might contribute to addressing this topic (see Kim 2002 for an introduction).

\section{DISCUSSION}

The Neolithic is an important transitional stage between the Late Paleolithic and the Bronze Age in Korea. A number of important socioeconomic changes occurred during this cultural period. In addition to the appearance of pottery during the Korean Neolithic, one of the most important changes is the transition from a diet that relied heavily on hunted, gathered, and fished items to full-scale agriculture by the advent of the Bronze Age. Although some authors (e.g. Lee 2011) argue that other researchers have created a "simple dichotomy" between the Neolithic and Bronze Age, in fact a great deal of evidence exists that show fairly conclusively that a great deal of variation existed in Korean Neolithic diets (see examples and references above). Furthermore, despite the growing evidence from zooarchaeology and geoscience research that supports arguments for substantial variation in Neolithic Korean diets, there is also significant variation between the overall diets of Neolithic and Bronze Age peoples in Korea (Norton 1996; Lee 2001; Kim 2002).

In addition, in light of the comprehensive list of AMS data accumulated in Korea over the past several years (see Appendix, online Supplemental Data), it is quite clear that variation in population density may have played some role in influencing dietary variation (contra Lee 2011). It is interesting that Lee (2011) tries to discount the possible role of migrations from the north. Indeed, Lee (2011: S327) writes "[n]ewcomers, if there were any, probably needed time to adjust to local environmental conditions, particularly for rice, which required irrigation techniques" (emphasis added). Although reconstructing human migration patterns through artifact variation is difficult at best on a good day, there seems to be at least some evidence that migrations or at least technologies diffused from the north (see Kim 2002 for discussion). For instance, Ahn (2010:97) notes "[r]ice agriculture, in conjunction with the beginning of the Mumun culture [Bronze Age], appeared from the late second millennium B.C. in the Korean peninsula under the influence of the Liaodong [northern China] Bronze Age culture. It soon spread quickly throughout the peninsula, apart from in the northeastern region." Furthermore, Norton (1996, 2000a, 2007), for example, has argued that sedentary life over the span of several millennia also contributed to growing population density during the Neolithic. Indeed, Kim and Bae (2010) were able to show that population increased at least 2-3 times during the Late Neolithic. Here, we presented evidence that population increase may have begun as early as the Early Neolithic. Thus, it is difficult to argue that increasing population through migrations and/or sedentism played little to no role in the substantial changes in Neolithic people's subsistence strategies that eventually culminated in full-scale agriculture by the beginning of the Bronze Age.

One commonly known feature of the Korean Peninsula (Norton 2000b; Kim 2002), which contrasts sharply with much of the Chinese mainland and which suggests the origins of agriculture and the related development of socioeconomic complexity in the 2 regions were not exactly the same, is the topography. Roughly $70 \%$ of the Korean Peninsula is covered with mountains, particularly the eastern half of the peninsula. This topography led to pockets of communities that, although not com- 


\section{Human Subsistence Strategies During Korean Neolithic}

pletely isolated, were likely not as extensively developed as the Chinese mainland, particularly the low-lying plains regions where agriculture initially took hold. Indeed, Kim (2002:11) notes that even the western half of the peninsula, which is generally flatter than the very mountainous eastern region, "contains only narrow basins: plains are mainly located along the major and secondary rivers and are surrounded by mountain ridges or low hills. Thus suitable agricultural land is patchily distributed." Given the topographic variation of the Korean Peninsula, it is perhaps not that surprising that small-scale cultivation appears patchily during the Middle Neolithic and it is not until the advent of the Bronze Age where full-scale agriculture takes hold. Movement to find better agricultural land likely started sometime during the Late Neolithic and probably did not occur "instantaneously" during the Early Bronze Age.

\section{CONCLUSION}

During 2 million years of generalized hunter/gatherers adaptation, those strategies did not change significantly. What ever the mechanism, it appears that in the face of repeated natural resource fluctuations of major and minor magnitudes, and of short and long duration, bands consistently chose to move out, curtail their numbers, fight with neighbors, or risk starvation rather than begin to produce food" (Hayden 1990: $34-5)$.

Although the above quotation is now more than 2 decades old, the question of agricultural origins around the world still continues to be heavily debated (e.g. O'Brien and Laland 2012; Price and BarYosef 2011; Zeder 2012). The Korean case has entered this debate with variable results (e.g. Norton 2007; Kim 2010; Lee 2011). Fortunately, the increase of AMS dates from Early and Middle Holocene sites in Korea is helping to better fill in the picture of this important debate.

What should be noted here is that although some models may better explain the origins of agriculture in Korea than others, all of the models to some extent raise valid points (Norton 1996, 2000a, 2007; Lee 2001; Kim 2002, 2010). Furthermore, these models are at least attempting to explain why after thousands of years of hunting, gathering, and fishing Korean Peninsula people made the transition to full-scale agriculture. Models that have been proposed are at least attempting to answer the processual "why" question in prehistoric studies.

\section{ACKNOWLEDGMENTS}

An earlier version of this paper was presented at the 2012 Radiocarbon Conference that was held in Paris, France. Funding for this study was provided by a grant from the Academy of Korean Studies, Korean Studies Promotion Service (AKS-2010-DZZ-3102). We appreciate the help of Kiryong Kim, Maureen Moffit, and Josephine Yucha with the figures and Appendix. Many thanks are due to the editor and 3 anonymous reviewers for their thoughtful comments. We take full responsibility for any errors that may be present.

\section{REFERENCES}

Ahn SM. 2010. The emergence of rice agriculture in Korea: archaeobotanical perspectives. Archaeological and Anthropological Sciences 2(2):89-98.

An DI. 1991. A study of the Konam-ri shell middens, Korea [PhD dissertation]. University of London.

An DI. 1994. Tongsam-dong shell midden and animal remains: focusing on the archaeological data from L. L. Sample's excavation. Journal of the Korean Archaeological Society 31:297-340.

Bae CJ, Bae KD. 2012. The nature of the Early to Late
Paleolithic transition in Korea: current perspectives. Quaternary International 281:26-35.

Bae CJ, Kim JC. 2010. The Late Paleolithic-Neolithic transition in Korea: current archaeological and radiocarbon perspectives. Radiocarbon 52(2):493-9.

Choe CP. 1982. The diffusion route and chronology of Korean plant domestication. Journal of Asian Studies 41:19-29.

Choe CP, Bale MT. 2002. Current perspectives on settlement, subsistence, and cultivation in prehistoric Ko- 


\section{K Bae et al.}

rea. Arctic Anthropology 39(1-2):96-121.

Choy KC, Richards MP. 2009. Stable isotope evidence of human diet at the Nukdo shell midden site, South Korea. Journal of Archaeological Science 36(7):1312-8.

Choy KC, Richards MP. 2010. Isotopic evidence for diet in the Middle Chulmun period: a case study from the Tongsamdong shell midden, Korea. Anthropological and Archaeological Sciences 2(1):1-10.

Choy KC, An DG, Richards MP. 2012. Stable isotopic analysis of human and faunal remains from the Incipient Chulmun (Neolithic) shell midden site of Ando Island, Korea. Journal of Archaeological Science 39(7):2091-7.

Crawford GW, Lee GA. 2003. Agricultural origins in Korea. Antiquity 77(295):87-95.

Gao X, Norton CJ. 2002. A critique of the Chinese "Middle Palaeolithic." Antiquity 76(392):397-412.

Hayden B. 1990. Nimrods, piscators, pluckers, and planters: the emergence of food production. Journal of Anthropological Archaeology 9:31-69.

Kim JS. 2003. Land-use conflicts and the rate of the transition to agricultural economy: a comparative study of southern Scandinavia and central-western Korea Journal of Archaeological Method and Theory 19(3): 277-321.

Kim B. 2006. Political economy of wet-rice production in the Bronze Age, central western Korea. Journal of the Korean Archaeological Society 58:40-65.

Kim JC, Bae CJ. 2010. Radiocarbon dates documenting the Neolithic-Bronze Age transition in Korea. Radiocarbon 52(2-3):483-92.

Kim JS. 2002. The Late Neolithic-Early Bronze Age transition and cessation of island exploitation in Central-Western Korea: the spread of territoriality into a mobile hunter-gatherer context [PhD dissertation]. Tempe: Arizona State University.

Kim JS. 2006. Resource patch sharing among foragers: lack of territoriality or strategic choice? In: Grier C, Kim JS, Uchiyama J, editors. Beyond Affluent Foragers: Rethinking Hunter-Gatherer Complexity. Oxford: Oxbow. p 168-91.

Kim JS. 2008. Socioeconomic implications of storage facilities of the Songgukri period. Journal of the Korean Archaeological Society 67:4-39.

Kim JS. 2010. Opportunistic versus target mode: prey choice changes in central-western Korean prehistory. Journal of Anthropological Archaeology 29(1):80-93.

Kim WY. 1986. Art and Archaeology of Ancient Korea Seoul: Taekwang Publishing.

Lee GA. 2011. The transition from foraging to farming in prehistoric Korea. Current Anthropology 52:S307S329.

Lee JJ. 2001. From shellfish gathering to agriculture in prehistoric Korea: the Chulmun to Mumun transition [PhD dissertation]. Madison: University of Wisconsin.

Lim S. 2009. The adoption process of agriculture and socioeconomic changes during the Chulmun period in the southern Korean peninsula. In: Ahn SM, Lee JJ, editors. New Approaches to Prehistoric Agriculture. Seoul: Sahoi Pyoungnon. p 144-71.

Nelson SM. 1993. The Archaeology of Korea. Cambridge: Cambridge University Press.

Norton CJ. 1996. Storage and its implications for the advent of rice agriculture in Korea: Konam-ri [MA thesis]. Tucson: University of Arizona.

Norton CJ. 2000a. Subsistence change at Konam-ri: implications of the advent of rice agriculture in Korea. Journal of Anthropological Research 56(3):325-48.

Norton CJ. 2000b. The current state of Korean paleoanthropology. Journal of Human Evolution 38:803-25.

Norton CJ. 2007. Sedentism, territorial circumscription, and the increased use of plant domesticates across Neolithic-Bronze Age Korea. Asian Perspectives 46(1):133-65.

Norton CJ, Kim BM, Bae KD. 1999. Differential processing of fish during the Korean Neolithic: Konamri. Arctic Anthropology 36(1-2):151-65.

Norton CJ, Bae KD, Lee HY, Harris JWK. 2007. A review of Korean microlithic industries. In: Keates S, Kuzmin Y, Shen C, editors. Origin and Spread of Microblade Technology in Northern Asia and North America. Vancouver: Archaeology Press. p 91-102.

O'Brien MJ, Laland KN. 2012. Genes, culture, and agriculture: an example of human niche construction. Current Anthropology 53(4):434-70.

Price TD, Bar-Yosef O. 2012. The origins of agriculture: new data, new ideas. Current Anthropology 52(4): S163-S174.

Reimer PJ, Baillie MGL, Bard E, Bayliss A, Beck JW, Blackwell PG, Bronk Ramsey C, Buck CE, Burr GS, Edwards RL, Friedrich M, Grootes PM, Guilderson TP, Hajdas I, Heaton TJ, Hogg AG, Hughen KA, Kaiser KF, Kromer B, McCormac FG, Manning SW, Reimer RW, Richards DA, Southon JR, Talamo S, Turney CSM, van der Plicht J, Weyhenmeyer CE. 2009. IntCa109 and Marine09 radiocarbon age calibration curves, 0-50,000 years cal BP. Radiocarbon 51(4): 1111-50.

Rhee SN, Choi ML. 1992. Emergence of complex society in prehistoric Korea. Journal of World Prehistory 6(1):51-95.

Sample LL. 1974. Tongsamdong: a contribution to Korean Neolithic culture history. Arctic Anthropology 11(2): $1-125$.

Seong CT. 2007. Late Pleistocene microlithic assemblages in Korea. In: Keates S, Kuzmin Y, Shen C, editors. Origin and Spread of Microblade Technology in Northern Asia and North America. Vancouver: Archaeology Press. p 103-14.

Stuiver M, Reimer PJ. 1993. Extended ${ }^{14} \mathrm{C}$ data base and revised CALIB $3.0{ }^{14} \mathrm{C}$ age calibration program. $R a-$ diocarbon 35(1):215-30.

Zeder MA. 2012. The broad spectrum revolution at 40: resource diversity, intensification, and an alternative to optimal foraging explanations. Journal of Anthropology Archaeology 31(3):241-4. 